\title{
A Possible Discordant Factor in the Standardization of Disinfectants.
}

BY

\section{J. T. AINSLIE WALKER, F.R.S.M., F.C.S., and JOHN MORRIS WEISS, B.S., B.A.}

WITH the development of chemistry as a quantitative science, used in many and diversified industries, a pressing demand for pure reagents arose. Methods for insuring the purity of chemicals used in quantitative analysis were developed, and to-day this feature has been brought to a state of high perfection. Bacteriology, on the other hand, is in the incipient stage of development along quantitative lines, and most phases are still empirical. One feature which to-day is susceptible of exact quantitative determination is the bactericidal standardization of disinfectants. This is best exemplified by the Rideal-Walker test, ${ }^{1}$ which, briefly, consists in comparing the strengths of disinfectants which kill B. typhosus in a definite time under carefully standardized conditions with the strength of pure phenol solution necessary to perform the same work under the same conditions. Various modifications have been suggested from time to time. ${ }^{2} \begin{array}{lllll}3 & 4 & 5 & 6 & 7\end{array}$. All, however, use pure phenol as a standard, and on the purity of this standard depends the accuracy of the test.

All previous workers have used the Koppeschar bromine titration method ${ }^{8}$ as the means of measuring the purity of their phenol control. This is admirable, so far as the detection and elimination of water are concerned, but it totally fails to indicate another and far more serious impurity.

Phenol, or pure crystal carbolic acid, is almost entirely manufactured from a distillate oil of coal-tar by an extraction process, with subsequent purification by distillation and crystallization. In these processes it is possible to produce a very pure phenol, but ordinarily this is not done. Phenol from such a source always contains some of the next higher homologuesthe cresols - the amount varying with the care given to the manufacturing process. The bromine titration does not indicate the

'Presented at the meeting of the Section of Physics and Chemistry held Thursday, April 25, Igr2. 
presence of moderate amounts of cresol in phenol, returning both in terms of the latter, the analytical variations due to this cause being negligible. As cresol has approximately three times the bactericidal efficiency of phenol, the error from this cause, as will be shown later, may be a very considerable one. The purpose of this communication is to present a new method for insuring the purity of phenol used in determinations of the bactericidal efficiency of disinfectants, and to show by experiment that the cause mentioned above probably accounts for many of the discordant results obtained in the past by different investigators. To insure a pure phenol as a basis for work, the material was synthesized from pure benzene by the Wurtz, Kekule and Dusart sulphonate method, and the product fractionally distilled twice to eliminate water and small amounts of by-products formed in the reaction. The crystallized phenol thus obtained had a solidifying point of $40.5^{\circ} \mathrm{C}$. Although some authorities place the melting point of pure phenol at figures varying from 40 to $42.5^{\circ} \mathrm{C}$., yet it has been conclusively shown by Eger ${ }^{9}{ }^{10}$ that the highest purity of phenol has a solidifying point of not over $40.9^{\circ} \mathrm{C}$. In view of the fact that our solidifying point was taken on a thermometer recently checked by the United States Bureau of Standards, and that the phenol itself boiled within very narrow limits $\left(0.5^{\circ} \mathrm{C}\right.$.), we felt justified in considering that our phenol was absolute, and that the figures as to melting point reported by earlier investigators were incorrect, either because of inaccurate thermometers, or from having to deal with too small quantities of material.

Mixtures of this pure phenol were then made with pure cresols, and it was found that with percentages of cresol from o to 30 the lowering of the melting point was constant for any particular degree of impurity, regardless of the variation of the proportions of the three isomeric cresols making up this impurity. The solidifying points were taken on at least 50 c.c. material with the thermometer in the liquid. The point is very sharp, as the thermometer shows a constant temperature over a period of from five to ten minutes.

A curve was plotted, using percentages of phenol as ordinates and solidifying points as abscissæ. From this curve it was possible to deduce from a solidifying point of a dried phenol the degree of cresol contamination. Four phenols obtained from various sources in the open market were thus tested. They were 
Note on the Rideal-Walker Phenol Control. iO3

dried before testing by heating about Ioo grammes in a distilling bulb until the vapor temperature reached $\mathrm{I} 7 \mathrm{O}^{\circ} \mathrm{C}$., experience having shown this to be completely adequate.

The results of these tests showed that the samples varied widely.

TABLE NO. 2.

Material.

Phenol No. I. . . . . . . . . . . 34.4 ${ }^{\circ} \mathrm{C}$.

Phenol No. 2............. $38.0^{\circ}$

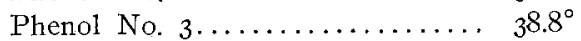

Phenol No. 4 ............. $39.9^{\circ}$

Phenol synthetic ......... $40.5^{\circ}$

FIG. I.

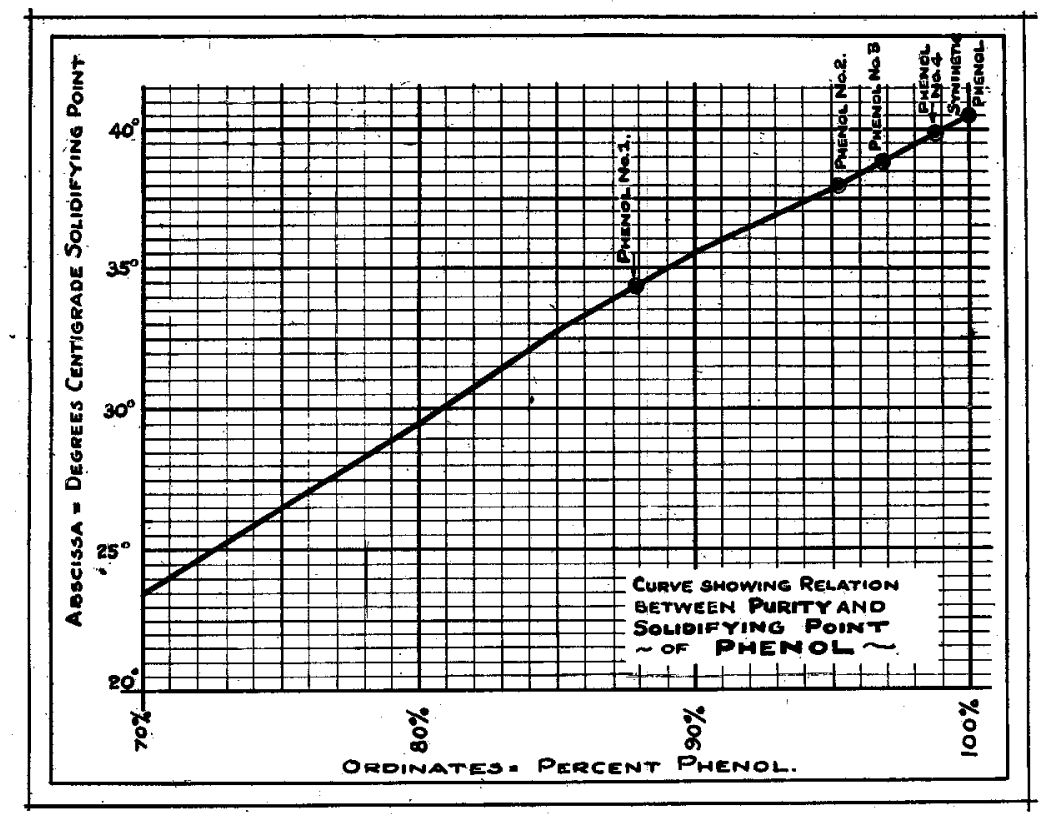

These are also shown graphically in the curve accompanying this paper, the points at which the various phenols fell being clearly indicated (see Fig: I).

Solutions of each of these, of approximately 5 per cent., were then made up in the following manner. About 50 grammes of dry substance were poured into a weighing bottle, stoppered, cooled and weighed to four places of decimals on a sensitive balance. The phenol was melted, then poured out into a litre flask, the weighing bottle being restoppered and reweighed. The 
litre flask was filled with water and carefully adjusted to the mark at $15.5^{\circ} \mathrm{C}$.

In order to determine if analytical results would indicate the cresol contamination appreciably, samples of these solutions were sent to the Lederle Laboratories of New York City, and there assayed for phenol by the bromine titration method. The results of these analyses are as follows:

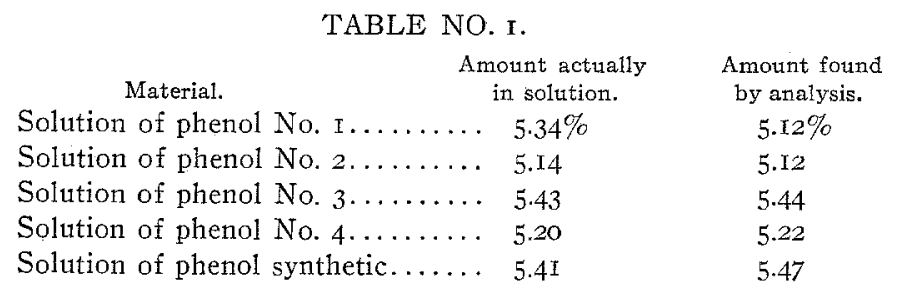

It can readily be seen, even in the extreme case of No. I, that the variation in test is one which would excite no suspicion and could very well, under ordinary circumstances, be attributed to experimental error. These solutions were then used in the bacteriological tests which follow.

A preliminary experiment with the particular strain of Bacillus typhosus (obtained through the courtesy of Dr. Park at the New York City Research Laboratories) established the fact that a I: I Io solution of synthetic phenol under RidealWalker normal conditions showed life up to $\mathrm{I} 2 \mathrm{~T} / 2$ minutes. This dilution was therefore taken in preparing standard solutions of the other four phenols to compare their relative germicidal values.

Five c.c. of each of these dilutions were transferred to a sterile test-tube by sterile pipettes. To each one of these tubes, at intervals of exactly thirty seconds, 5 drops of a 24 hours' culture of $B$. typhosus incubated at $37^{\circ} \mathrm{C}$. in Rideal-Walker standard broth were added (the pipette used delivered drops of distilled water weighing approximately 0.05 gramme), and the half-minute interval was accurately continued whilst 30 broth tubes were inoculated with a single loopful of the medicated cultures. Throughout the experiment the temperature of the water bath in which the medication tubes were immersed was maintained at $15^{\circ} \mathrm{C}$. Table No. 3 shows the results obtained after the 30 sub-culture tubes were incubated for 48 hours. 
To show to what extent these various phenols would affect the coefficient of a disinfectant when used as standard controls, R.-W. determinations were made, taking the same high coeffcient disinfectant as the postulant in each case. The results are seen in Tables Nos. 4, 5, 6, 7 and 8, whole multiples of the control dilution being taken in each case when preparing the dilutions of the postulant.

It is interesting, in this connection, to note that the results obtained agree very closely with the calculated theoretical figures, taking the coefficient of cresol as 3.0 (see Table No. 9). It is quite conceivable, had the experiments been conducted with half multiples when preparing the yarious dilutions for test, that the results might have agreed even more closely.

\section{TABLE NO. 3 .}

B. Typhosus, 24 hours' Broth Culture at $37^{\circ} \mathrm{C}$.

Temperature of Water-bath $15^{\circ} \mathrm{C}$.

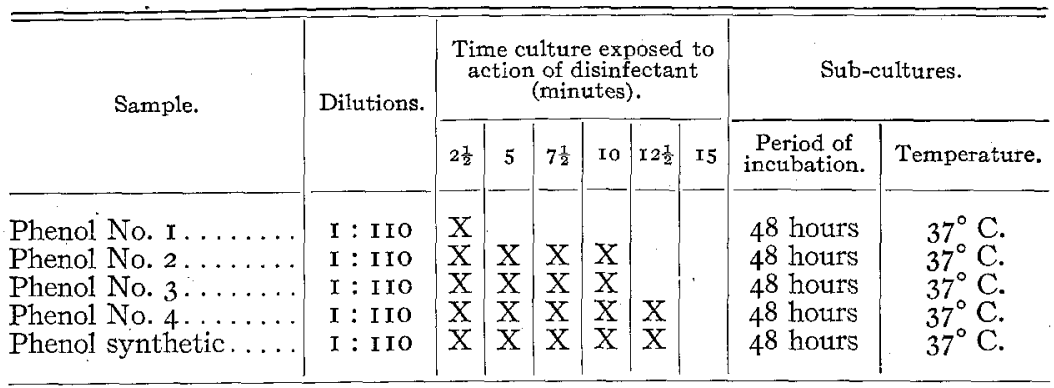

TABLE NO. 4.

B. Typhosus, 24 hours' Broth Culture at $37^{\circ} \mathrm{C}$.

Room Temperature $15^{\circ}-18^{\circ} \mathrm{C}$.

\begin{tabular}{|c|c|c|c|c|c|c|c|c|c|}
\hline \multirow{2}{*}{ Sample. } & \multirow{2}{*}{ Dilutions. } & \multicolumn{6}{|c|}{$\begin{array}{l}\text { Time culture exposed to } \\
\text { action of disinfectant } \\
\text { (minutes). }\end{array}$} & \multicolumn{2}{|c|}{ Sub-cultures. } \\
\hline & & $2 \frac{1}{2}$ & 5 & $7 \frac{1}{2}$ & Io & I $2 \frac{1}{2}$ & I5 & $\begin{array}{c}\text { Period of } \\
\text { incubation. }\end{array}$ & Temperature. \\
\hline 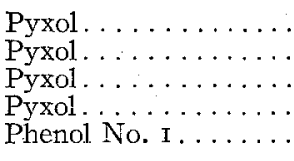 & 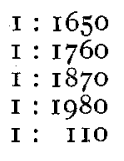 & $\begin{array}{l}X \\
X \\
X \\
X\end{array}$ & $\begin{array}{l}\mathrm{X} \\
\mathrm{X}\end{array}$ & $\begin{array}{l}X \\
X\end{array}$ & $\mathrm{X}$ & & & $\begin{array}{l}48 \text { hours } \\
48 \text { hours } \\
48 \text { hours } \\
48 \text { hotirs } \\
48 \text { hours }\end{array}$ & $\begin{array}{l}37^{\circ} \mathrm{C} . \\
37^{\circ} \mathrm{C} . \\
37^{\circ} \mathrm{C} . \\
37^{\circ} \mathrm{C} . \\
37^{\circ} \mathrm{C} .\end{array}$ \\
\hline
\end{tabular}

$\therefore$ Rideal-Walker Coefficient $\frac{\mathrm{I} 760}{\mathrm{IIO}}=\mathrm{I} 6.0$. 
TABLE NO. 5 .

B. Typhosus, 24 hours' Broth Culture AT $37^{\circ} \mathrm{C}$. Room Temperature $15^{\circ}-18^{\circ} \mathrm{C}$.

\begin{tabular}{|c|c|c|c|c|c|c|c|c|c|}
\hline \multirow{2}{*}{ Sample. } & \multirow{2}{*}{ Dilutions. } & \multicolumn{6}{|c|}{$\begin{array}{l}\text { Time culture exposed to } \\
\text { action of disinfectant } \\
\text { (mirutes). }\end{array}$} & \multicolumn{2}{|c|}{ Sub-cultures. } \\
\hline & & $2 \frac{1}{2}$ & 5 & $7 \frac{1}{2}$ & I0 & $12 \frac{1}{2}$ & I5 & $\begin{array}{l}\text { Period of } \\
\text { incubation. }\end{array}$ & Temperature. \\
\hline $\begin{array}{l}\text { Pyxol } \ldots \ldots \\
\text { Pyxol } \ldots \ldots \\
\text { Pyxol } \ldots \ldots \\
\text { Pyxol } \ldots \\
\text { Phenol No. } 2 \ldots \\
\end{array}$ & $\begin{array}{l}\text { I }: \text { I } 7 \text { I0 } \\
\text { I }: \text { I } 805 \\
\text { I }: 1900 \\
1: 1995 \\
\text { I }: \quad 95\end{array}$ & $\begin{array}{l}X \\
X \\
X \\
X \\
X\end{array}$ & $\begin{array}{l}X \\
X \\
X \\
X\end{array}$ & $\begin{array}{l}\mathrm{X} \\
\mathrm{X} \\
\mathrm{X}\end{array}$ & $\begin{array}{l}X \\
X\end{array}$ & $\mathrm{X}$ & & $\begin{array}{l}48 \text { hours } \\
48 \text { hours } \\
48 \text { hours } \\
48 \text { hours } \\
48 \text { hours }\end{array}$ & $\begin{array}{l}37^{\circ} \mathrm{C} \\
37^{\circ} \mathrm{C} \\
37^{\circ} \mathrm{C} \\
37^{\circ} \mathrm{C} \\
37^{\circ} \mathrm{C}\end{array}$ \\
\hline
\end{tabular}

$\therefore$ Rideal-Walker Coefficient $\frac{17 \text { IO }}{95}, \frac{1805}{95}=\mathrm{I} 8.5$ (average).

TABIE NO. 6.

B. Typhosus, 24 hours' Broth Culture at $37^{\circ} \mathrm{C}$.

Room Temperature $\mathrm{I} 5^{\circ}-\mathrm{I} 8^{\circ} \mathrm{C}$.

\begin{tabular}{|c|c|c|c|c|c|c|c|c|c|}
\hline \multirow{2}{*}{ Sample. } & \multirow{2}{*}{ Dilutions. } & \multicolumn{6}{|c|}{$\begin{array}{l}\text { Time culture exposed to } \\
\text { action of disinfectant } \\
\text { (minutes). }\end{array}$} & \multicolumn{2}{|c|}{ Sub-cuttures. } \\
\hline & & $2 \frac{1}{2}$ & 5 & $7 \frac{1}{2}$ & ro & $12 \frac{1}{2}$ & I5 & $\begin{array}{c}\text { Period of } \\
\text { incubation. }\end{array}$ & Temperature. \\
\hline 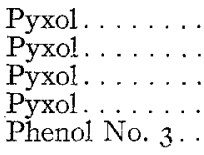 & 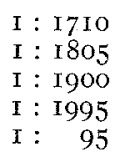 & $\begin{array}{l}\mathrm{X} \\
\mathrm{X} \\
\mathrm{X} \\
\mathrm{X} \\
\mathrm{X}\end{array}$ & $\begin{array}{l}X \\
X \\
X \\
X\end{array}$ & $\begin{array}{l}X \\
X\end{array}$ & $\begin{array}{l}X \\
X\end{array}$ & X & & $\begin{array}{l}48 \text { hours } \\
48 \text { hours } \\
48 \text { hours } \\
48 \text { hours } \\
48 \text { hours }\end{array}$ & $\begin{array}{l}37^{\circ} \mathrm{C} \\
37^{\circ} \mathrm{C} \\
37^{\circ} \mathrm{C} \\
37^{\circ} \mathrm{C} \\
37^{\circ} \mathrm{C}\end{array}$ \\
\hline
\end{tabular}

$$
\therefore \text { Rideal-Walker Coefficient } \frac{1805}{95}=\text { I9.0. }
$$

TABLE NO. 7 .

B. Typhosus, 24 hours' Broth Culture at $37^{\circ} \mathrm{C}$.

Room Temperature $15^{\circ}-\mathrm{I} 8^{\circ} \mathrm{C}$.

\begin{tabular}{|c|c|c|c|c|c|c|c|c|c|}
\hline \multirow{2}{*}{ Sample. } & \multirow{2}{*}{ Dilutions. } & \multicolumn{6}{|c|}{$\begin{array}{l}\text { Time culture exposed to } \\
\text { action of disinfectant } \\
\text { (minutes). }\end{array}$} & \multicolumn{2}{|c|}{ Sub-cultures. } \\
\hline & & $2 \frac{1}{2}$ & 5 & $7 \frac{1}{2}$ & IO & I $2 \frac{1}{2}$ & I5 & $\begin{array}{l}\text { Period of } \\
\text { incubation. }\end{array}$ & Temperature. \\
\hline $\begin{array}{l}\text { Pyxol. . . . . . . . . } \\
\text { Pyxol. . . . . . . . . } \\
\text { Pyxol . . . . . . . } \\
\text { Pyxol . . . . . . . } \\
\text { Phenol No. } 4 \text {. . . }\end{array}$ & $\begin{array}{r}\text { I }: 1710 \\
\text { I }: 1800 \\
1: 1890 \\
1: 1980 \\
1: 90\end{array}$ & $\begin{array}{l}X \\
X \\
X \\
X \\
X\end{array}$ & $\begin{array}{l}X \\
X \\
X \\
X\end{array}$ & $\begin{array}{l}X \\
X\end{array}$ & $\mathrm{X}$ & & & $\begin{array}{l}48 \text { hours } \\
48 \text { hours } \\
48 \text { hours } \\
48 \text { hours } \\
48 \text { hours }\end{array}$ & $\begin{array}{l}37^{\circ} \mathrm{C} \\
37^{\circ} \mathrm{C} \\
37^{\circ} \mathrm{C} \\
37^{\circ} \mathrm{C} \\
37^{\circ} \mathrm{C} .\end{array}$ \\
\hline
\end{tabular}

$\therefore$ Rideal-Walker Coefficient $\frac{1800}{90}=20.0$. 
Note on the Rideal-Walker Phenol Control. io7

TABLE NO. 8.

B. Typhosus, 24 hours' Broth Culture at $37^{\circ} \mathrm{C}$.

Room Temperature $r 5^{\circ}-18^{\circ} \mathrm{C}$.

\begin{tabular}{|c|c|c|c|c|c|c|c|c|c|}
\hline \multirow{2}{*}{ Sample. } & \multirow{2}{*}{ Dilutions. } & \multicolumn{6}{|c|}{$\begin{array}{l}\text { Time culture exposed to } \\
\text { action of disinfectant } \\
\text { (minutes). }\end{array}$} & \multicolumn{2}{|c|}{ Sub-cultures. } \\
\hline & & $2 \frac{1}{2}$ & 5 & $7 \frac{1}{2}$ & ro & I2 $2 \frac{1}{2}$ & I5 & $\begin{array}{c}\text { Period of } \\
\text { incubation. }\end{array}$ & Temperature. \\
\hline $\begin{array}{l}\text { Pyxol. } \ldots \ldots \ldots \ldots \\
\text { Pyxol. } \ldots \ldots \ldots \ldots \ldots \\
\text { Pyxol. } \ldots \ldots \ldots \ldots \\
\text { Pyxol. } \ldots \ldots \ldots \ldots \\
\text { Phenol synthetic . }\end{array}$ & $\begin{array}{l}\text { I : } 1710 \\
\text { I : } 1800 \\
\text { I : } 1890 \\
\text { I : } 1980 \\
\text { I: } \quad 90\end{array}$ & $\begin{array}{l}X \\
X \\
X \\
X\end{array}$ & $\begin{array}{l}X \\
X \\
X \\
X\end{array}$ & X & $\mathrm{X}$ & & & $\begin{array}{l}48 \text { hours } \\
48 \text { hours } \\
48 \text { hours } \\
48 \text { hours } \\
48 \text { hours }\end{array}$ & $\begin{array}{l}37^{\circ} \mathrm{C} . \\
37^{\circ} \mathrm{C} \\
37^{\circ} \mathrm{C} \\
37^{\circ} \mathrm{C} \\
37^{\circ} \mathrm{C} .\end{array}$ \\
\hline
\end{tabular}

TABLE NO. 9.

Material

Phenol No. I............. I6.0

Phenol No. 2............ I8.5

Phenol No. 3............ I9.o

Phenol No. $4 \ldots \ldots \ldots \ldots \ldots .20 .0$

Phenol synthetic ......... 20.0
RIDEAL-WALKER coefficient calculated.

I6.I2

18.25

I8.56

19.56

20.00

\section{GENERAL SUMMARY.}

I. Phenol crystals are usually contaminated by cresols to such an extent as to make them unreliable for purposes of bactericidal control.

2. This impurity depresses the coefficient of a disinfectant.

3. The bromine titration is insufficient to insure the purity of phenol.

4. The purity must be first determined before the phenol is selected for use.

5. The purity should be established by determination of the solidifying point as outlined in the present paper.

6. The bromine titration should be used as a check on the gravimetric preparation of the stock 5 per cent. solution.

7. The authors present as a recommendation that no phenol showing a solidifying point of less that $40^{\circ} \mathrm{C}$. be used for purposes of bactericidal control. 
REFERENCES.

${ }^{1}$ Rideal and Walker, Jour. Royal San. Inst., vol. xxiv, I903, p. 424.

${ }^{2}$ Chick and Martin, Jour. Hygiene, vol, viii, No. 5, Nov., rgo8, p. 665.

${ }^{3}$ Anderson and McClintic, Jour. Infect. Dis., vol. viii, No. I, Jan., Igr. r, p. r.

${ }^{4}$ Woodhead and Ponder, Lancet, I909, ii, pp. I454, I516, I6r2.

${ }^{5}$ Wynter Blyth, Jour. Soc. Chem. Ind., Dec. 31, 1906.

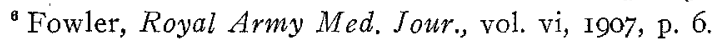

' Sommerville and Walker, San. Record, Nov. 29, Igo6; May 9, I907; March $26,1908$.

${ }^{8}$ Koppeschar, Z. anal Chem, 1886, p. 233.

${ }^{2}$ Pharm. Zeit., I903, p. 2 Io.

${ }^{10}$ Chem. Zeit. Rep., 1903, p. 86.

\section{ABSTRACTS OF COMMUNICATED DISCUSSIONS.}

My principal comment would be that the proposal to use only phenol having a solidifying point of not less than $40^{\circ} \mathrm{C}$. appears superfluous, because of the fact that the United States Pharmacopœia, 8th Revision, official from September I, I905, recognized as a legal standard in such matters by Act of Congress of June 30, I906, already provides that phenol shall have a solidifying point not lower than $40^{\circ} \mathrm{C}$. In view of the foregoing, I would deem it the duty of all analysts, in making tests requiring the use of phenol as a standard substance, to adhere, as a matter of course, to a standard at least no lower than that set by the 8th Revision of the United States Pharmacopœia. I have myself tested various samples of phenol supplied in the ordinary course of laboratory routine, and have had no difficulty in obtaining samples complying with the U. S. P. requirement. I have further made inquiries from large manufacturing houses who use but do not manufacture phenol, and who inform me that they have no difficulty in obtaining phenol as above. I am, therefore, forced to think that the samples mentioned by Mr. Walker must have been of materials decidedly below the quality readily obtainable in the market.-Dr. G. H. Meerer, Dean, Dept. of Pharmaceutic Chemistry, The Medico-Chirurgical College, Philadelphia, $\mathrm{Pa}$.

The paper suggests a new, or rather an additional, procedure to be followed in testing phenol as to its suitability for use in the determination of the Rideal-Walker coefficient.

All previous workers, it appears, used a chemical test for this purpose, the well-known Koppeschar volumetric method, using bromine. A chemical method is obviously unsuited for 